\title{
Judging Responsibility, Responsible Judging
}

\section{Citation}

John C. Goldberg, Judging Responsibility, Responsible Judging, 64 DePaul L. Rev. 475 (2015).

\section{Published Version}

http://via.library.depaul.edu/law-review/vol64/iss2/11

\section{Permanent link}

http://nrs.harvard.edu/urn-3:HUL.InstRepos:21531721

\section{Terms of Use}

This article was downloaded from Harvard University's DASH repository, and is made available under the terms and conditions applicable to Other Posted Material, as set forth at http:// nrs.harvard.edu/urn-3:HUL.InstRepos:dash.current.terms-of-use\#LAA

\section{Share Your Story}

The Harvard community has made this article openly available.

Please share how this access benefits you. Submit a story.

\section{Accessibility}




\section{DePAULUNIVERSITY UNIVERSITY LIBRARIES}

\section{DePaul Law Review}

Volume 64

Issue 2 Winter 2014: Twentieth Annual Clifford

Symposium on Tort Law and Social Policy -

Article 11

Symposium: In Honor of Jack Weinstein

\section{Judging Responsibility, Responsible Judging}

John C.P. Goldberg

Follow this and additional works at: http://via.library.depaul.edu/law-review

\section{Recommended Citation}

John C. Goldberg, Judging Responsibility, Responsible Judging, 64 DePaul L. Rev. (2015)

Available at: http://via.library.depaul.edu/law-review/vol64/iss2/11

This Article is brought to you for free and open access by the College of Law at Via Sapientiae. It has been accepted for inclusion in DePaul Law Review by an authorized administrator of Via Sapientiae. For more information, please contact mbernal2@depaul.edu, MHESS8@depaul.edu. 


\title{
JUDGING RESPONSIBILITY, RESPONSIBLE JUDGING
}

\author{
John C. P. Goldberg*
}

\section{INTRODUCTION}

I am honored to have this opportunity to pay public tribute to Judge Weinstein. The most important things to say about him are the most obvious. He is superhuman-learned and wise beyond measure, eternally curious, impossibly energetic, deeply compassionate, fiercely determined, and completely charming. He has also been, and still is, an extraordinary public servant. As a lawyer, government official, judge, and legal scholar, he has devoted his life to the well-being of others, especially the vulnerable. Simply put, there are precious few who can claim to have done as much, and lived as well, as Jack Weinstein.

I will take this occasion to sketch out two ways in which Judge Weinstein's performance as a district judge raises issues of responsibility. First, I will consider how he has understood and applied concepts of responsibility central to tort law. Unsurprisingly, I will claim that, in his efforts to do "equity" through mass tort litigation, ${ }^{1}$ he has sometimes stretched these concepts quite far. This claim in turn raises a second set of questions about responsibility — namely, questions about the role responsibilities of a federal district court judge. Responding to those who criticize Judge Weinstein for being an "activist" whose decisions exceed the bounds of his office, I will contend that, notwithstanding his creativity, he has acted in a manner faithful to his official responsibilities. Indeed, I will show that, in important respects, he has acted more responsibly than other judges, including some who take pride in being "restrained."

* Eli Goldston Professor of Law, Harvard Law School; law clerk to Judge Weinstein, 1991-1992. Thanks to John Manning, Bill Rubenstein, Tony Sebok, and Ben Zipursky for very helpful comments, and to Charles Nelson for valuable research assistance. Remaining errors are my own.

1. Judge Weinstein has frequently maintained that his efforts at mass claims resolution are an outgrowth of, and supported by, traditional understandings of courts' equitable powers. See, e.g., Jack B. Weinstein, Individual Justice in Mass Tort Litigation: The Effect of Class Actions, Consolidations, and Other Multiparty Devices 123-62 (1995). 


\section{Judging ResPONSIBILITY}

Tort law identifies individual responsibilities - that is, duties that individuals owe to one another. ${ }^{2}$ Every tort specifies, at a general level, a way in which a person must refrain from wrongfully injuring another. For example, in recognizing the tort of battery, courts instruct us-or remind us, anyway - that we must refrain from intentionally touching others in a harmful or offensive manner. Strict products liability law "tells" commercial product sellers that they must avoid injuring consumers by sending dangerously defective products into commerce. Not coincidentally, tort law also enables victims to hold tortfeasors responsible for failures to live up to their responsibilities. The same law that defines battery and defective products liability grants victims of these injurious wrongs the power to bring a proceeding that, if successful, enables them to hold to account the batterer and the seller of defective products.

Tort law secondly presupposes and instantiates a notion of governmental responsibility. Social contract theory helpfully conveys the idea. When we enter into civil society, we give up our prepolitical privilege to respond directly to mistreatment. Concomitantly, government places significant legal limits on redress through self-help. In doing so, government incurs a duty to provide us with alternative avenues of redress. ${ }^{3}$

As even this thumbnail description may suggest, tort notions of responsibility are deeply individualistic. A tort is, canonically, one person's doing unto another, and a tort suit is an effort by the person onto whom injury has been done to hold the wrongdoer answerable to her. The state provides tort law in fulfillment of a duty owed to each citizen to provide a law of wrongs and recourse. It fulfills that duty by empowering individuals to hale alleged wrongful injurers into court for a proceeding that aims in the first instance to vindicate putative victims' interests, rather than those of the state or the public.

Other aspects of modern government and law appropriately embody different and less individualistic notions of responsibility. For example, programs that aim to provide a social safety net are animated, in part, by the idea that we collectively are responsible for ensuring that all members of the polity have access to certain necessities. The operative idea here has little to do with how one is obligated

2. For elaborations on the following sketch of tort law, see generally JoHN C. P. GoldBerg \& Benjamin C. Zipursky, The Oxford Introductions to U.S. Law: Torts (2010); John C. P. Goldberg \& Benjamin C. Zipursky, Torts as Wrongs, 88 Tex. L. Rev. 917 (2010).

3. John C. P. Goldberg, The Constitutional Status of Tort Law: Due Process and the Right to a Law for the Redress of Wrongs, 115 YALE L.J. 524, 544 (2005). 
to conduct oneself toward others, which is why individual duties associated with this kind of responsibility can probably be discharged by supporting a governmental tax-and-transfer system. And this kind of responsibility obviously calls for a different sort of state apparatus than the provision of courts as dispute resolvers and law articulators.

The foregoing contrast notwithstanding, it is critical to avoid the mistake of associating tort law's individualism with atomism, classical liberalism, or libertarianism. Atomistic conceptions of society envision a social world made up of citizens who share little beyond a physical space, and who occasionally interact, for better or for worse, as they pursue individual projects. ${ }^{4}$ The common law of tort, by contrast, presupposes and reinforces broadly shared social norms as to what counts as a wrongful injuring. Moreover, tort is all about the ways in which one must adjust one's own conduct in light of the interests of others-adjustments that often include not merely refraining from undertaking certain actions but also taking affirmative measures to avoid injuring or to protect others.

Libertarian political theory supposes that the government acts legitimately only insofar as it protects certain basic individual rights, such as the right to security of person and property from invasion by others. The state's job, on this view, is to create a safe space for competent adults to make the arrangements they wish to make. Tort, by contrast, imposes obligations as a matter of law, around which individuals usually are not permitted to contract. And while the modern welfare state might in some instances supplant or render superfluous certain applications of tort law, there is nothing about tort law that suggests it is incompatible with modern egalitarian conceptions of liberalism. To note the obvious, the common law of tort has for decades operated as a well-integrated part of the modern welfare states of Britain, Canada, and the United States. To repeat: tort notions of responsibility are individualistic, not laissez-faire.

To emphasize that tort law revolves around notions of individual responsibility is also not to suggest that tort law has remained constant or static since its antecedents first emerged in the courts of thirteenthcentury England. Quite obviously, modern courts have extended tort law in ways that medieval English lawyers could not have imagined and that more modern English judges would have deemed (and did deem) outrageous. ${ }^{5}$ At its core, tort law is still about an actor who

4. See generally C.B. MacPherson, The Political Theory of Possessive Individualism: Hobbes to Locke (1962).

5. Winterbottom v. Wright, (1842) 152 Eng. Rep. 402 (K.B.) 404-05; 10 M. \& W. 108, 113-15 (opinion of Lord Abinger, C.B.) (supposing that "absurd and outrageous consequences" would 
does unto another so as to injure that other. Yet courts have extended in various ways who counts as an "actor," as well as what counts as a "doing" and as an "injury." Sometimes, they have done so by expanding the class of actors who can be made to answer for breaches of duties. At other times, they have done so by recognizing new duties.

The notion that one person might sometimes be liable for the tort of another is hardly newfangled. For centuries-most notably through the doctrine of respondeat superior-courts have imputed acts of natural persons to other natural persons or incorporeal entities, primarily through principles of agency law. ${ }^{6}$ And yet modern classics such as Ybarra v. Spangard 7 -in which the California Supreme Court held that the nurses, doctors, and administrators who arranged for and performed the plaintiff's surgery could be treated as a single tortfeasor for purposes of the patient's negligence claim-have further extended these notions of imputation. ${ }^{8}$

With respect to duties of conduct, modern courts have shown a greater willingness than their predecessors to extend individual responsibility for injuries across time, space, and complex causal sequences. That a dangerously defective product is sold through an elaborate chain of commerce no longer relieves a manufacturer of its responsibilities to consumers or bystanders who might be injured by the product. ${ }^{9}$ Actors will sometimes also be held responsible for failing to protect victims against a third party's intentional wrongdoing, as in the case of a landlord charged with a duty to take measures to protect tenants from attacks in the public areas of the building. ${ }^{10}$ At the same time, courts continue to draw significant limits on what sort of causal sequences between wrongful act and injury can generate a tort. The landlord's liability turns on the presence of a special affirmative duty to protect of a sort that courts have recognized only sparingly. Absent such a duty, independent intentional wrongdoing will tend to count as a superseding cause, as evidenced by most courts' rejection of social host liability and of "negligent enabling" theories more generally. ${ }^{11}$

result if a manufacturer who sells a product to a buyer could be held liable in tort to third parties injured by the product).

6. See 1 William Blackstone, Commentaries *410, *417-19 (discussing vicarious liability of masters for the tortious acts of their servants).

7. 154 P.2d 687 (Cal. 1944).

8. Id. at 691 .

9. MacPherson v. Buick Motor Co., 111 N.E. 1050, 1053 (N.Y. 1916).

10. See, e.g., Kline v. 1500 Mass. Ave. Apt. Corp., 439 F.2d 477, 483 (D.C. Cir. 1970).

11. John C. P. Goldberg \& Benjamin C. Zipursky, Intervening Wrongdoing in Tort: The Restatement (Third)'s Unfortunate Embrace of Negligent Enabling, 44 WAKE Forest L. Rev. 1211, 1218-44 (2009). 
Victim responsibility is also an aspect of the tort notion of a "doing unto." Roughly speaking, the more substantial the plaintiff's contribution to her own injuries, the worse tort's doing-unto paradigm fits. Here again, courts and legislatures have been at work, most visibly by swapping out the all-or-nothing rule of contributory negligence for comparative fault. Again, however, the movement has been circumscribed. Most states have adopted modified comparative fault schemes that continue to recognize liability cutoffs. ${ }^{12}$ Thus, even in modern tort law, the plaintiff's contribution to her own injury sometimes renders it inappropriate to deem the defendant to have tortiously injured the plaintiff, even granted that the defendant's misconduct was a necessary condition for the occurrence of the injury.

One way to gain a sense of Judge Weinstein's approach to his job as a judge is to consider the ways in which his handling of mass tort cases has pushed on the foregoing concepts of individual and political responsibility. Indeed, it seems fair to say that, in aiming for "individual justice in a mass society," 13 the Judge has gone further in reworking these concepts than most other judges, and has done so even though it is not the business of the federal courts to fashion a general common law of tort. ${ }^{14}$

Judge Weinstein has always insisted that modern tort law must adapt to the conditions of mass society. By this he has meant, in part, that courts are entitled to further broaden the ideas of who can count as a tortfeasor, what can count as tortious conduct, and what will suffice as a cognizable injury. Not surprisingly, given his deep appreciation of the ways in which substantive law interacts with the law of evidence and procedure, he has made his case for this expansionary approach by reference to a blend of considerations.

Procedurally, the font of his approach has been Rule 23 of the Federal Rules of Civil Procedure. ${ }^{15}$ The enactment of that rule, in his view, established that federal courts enjoy the authority to use class action rules and related procedural devices to resolve personal injury claims on a collective basis. The ancient notion of an individual victim seeking redress through a lawsuit that aims to establish a defendant's responsibility for having wrongfully injured the victim has been supplanted, in mass accident cases, by the idea of a court summoning all potential claimants and defendants to appear before it-roughly in the manner of an interpleader action or a bankruptcy proceeding-so

12. Id. at $1229-31$.

13. See generally WeInstein, supra note 1, at 119-21.

14. Erie R.R. Co. v. Tompkins, 304 U.S. 64, 78 (1938).

15. E.g., WeINSTEIN, supra note 1 , at 134-36. 
that the court can arrange for a fair distribution of compensation. In these aggregate proceedings, notions of wrongdoing and individual responsibility are attenuated, sometimes drastically.

Judge Weinstein is, of course, no less a master of evidence than he is of civil procedure. ${ }^{16}$ Wearing this hat, he has long been a staunch advocate for the admissibility of statistical and probabilistic evidence, and of judicial reliance on independent experts. The use of statistical analysis points toward an aggregate, nonindividualized inquiry as to causation of injury. Indeed, its logical endpoint might well be the elimination of the usual tort requirement of proof of a defendant's having caused the plaintiff's injury. ${ }^{17}$ Much the same goes for the use of statistical analysis to compute damages-there is little or less concern to establish what happened to a particular claimant as a result of a defendant's tortious conduct, and instead an effort to create grids or tables roughly on the model of workers' compensation schemes. ${ }^{18}$

An early and important example of Judge Weinstein meshing procedural and evidentiary considerations of the sort just described with a reformist attitude toward substantive tort law is his adoption of the notion of "industry-wide" liability in the Hall and Chance decisions. ${ }^{19}$ In Chance, suits were brought on behalf of thirteen children injured by explosives that were alleged to lack adequate warnings and to have been defectively designed because they were too easily detonated. The explosives were manufactured by six companies comprising nearly the entire industry. The evidence did not allow for the matching of plaintiffs to defendants - it was not known which company's explosives caused which injury or injuries.

Judge Weinstein joined the actions and ruled that the manufacturers and their trade association could be held jointly liable even if the evidence showed only that the "defendants, acting independently, adhered to an industry-wide standard or custom with regard to the safety

16. See, e.g., Jack B. Weinstein et al., Evidence: Cases and Materials (9th ed. 1997); Jack B. Weinstein et al., New York Civil Practice (1963).

17. Margaret A. Berger, Essay, Eliminating General Causation: Notes Toward a New Theory of Justice and Toxic Torts, 97 Colum. L. Rev. 2117, 2117 (1997) (arguing, in an essay honoring Judge Weinstein, that "the substantive law governing toxic torts must be recast by abolishing proof of general causation"); see also David Rosenberg, The Causal Connection in Mass Exposure Cases: A "Public Law" Vision of the Tort System, 97 Harv. L. Rev. 849, 859 (1984) (proposing to replace traditional proof-of-causation requirements with a probabilistic scheme of proportional liability); WeInsteIn, supra note 1, at 151-52 (favorably citing, though noting difficulties with, Professor Rosenberg's proposal).

18. Weinstein, supra note 1 , at 155-59.

19. Hall v. E.I. Du Pont De Nemours \& Co., 345 F. Supp. 353, 370-80 (E.D.N.Y. 1972) (denying dismissal in both Hall and Chance v. E.I. Du Pont De Nemours \& Co.). 
features of blasting caps."20 Invoking respondeat superior, retailers' strict liability for defective products, Ybarra ${ }^{21}$ and Summers v. Tice, ${ }^{22}$ he reasoned that adherence by independent firms within an industry to a common set of safety protocols could suffice to establish joint responsibility for a "collective risk" posed to the class of potential victims. $^{23}$ Taken at face value, this rationale would, for cases in which plaintiffs face similar evidentiary obstacles, subject entire industries to liability for the actions of a single manufacturer, so long as that manufacturer's tortious conduct conformed to industry custom.

To my knowledge, no other court has embraced industry-wide liability. But Hall and Chance would later serve as inspiration for the California Supreme Court's adoption of market share liability in the famous Sindell decision. ${ }^{24}$ There, a defective generic drug, Diethylstilbestrol (DES), produced by numerous manufacturers allegedly caused thousands of victims to suffer a rare form of cancer as a result of in utero exposure. As in Chance, there was no feasible way to match particular victims to particular tortfeasors. The court held that under these conditions liability could be assigned according to each defendant's market share. That way, in the run of cases, each tortfeasor would be held responsible, more or less, for the torts it actually committed.

Sindell has been influential in setting out a basic template for how to think about the resolution of mass tort claims, and in particular, how to structure settlements. Nonetheless, it is almost as much of an outlier, doctrinally, as Chance and Hall. ${ }^{25}$ A few other courts, including the New York Court of Appeals, have adopted versions of market share liability in DES cases. ${ }^{26}$ But others have rejected it. ${ }^{27}$ And there are at best a handful of high court decisions applying market share liability to other products. ${ }^{28}$

20. Id. at 374 .

21. See supra note $7-8$ and accompanying text.

22. Summers v. Tice, 199 P.2d 1, 5 (Cal. 1948) (holding that, in a situation in which only one of two identically careless actors injured the victim, yet each of the two was just as likely as the other to have been the person who actually injured the victim, both would be deemed responsible unless one could disprove that it was his carelessness that injured the plaintiff).

23. Hall, 345 F. Supp. at 374.

24. Sindell v. Abbott Labs., 607 P.2d 924 (Cal. 1980), cert. denied, 449 U.S. 912 (1980).

25. Kenneth S. Abraham, Stable Divisions of Authority, 44 Wake Forest L. Rev. 963, 965 (2009).

26. See Conley v. Boyle Drug Co., 570 So. 2d 275, 283 (Fla. 1990); see also Hymowitz v. Eli Lilly \& Co., 539 N.E.2d 1069, 1071-73 (N.Y. 1989); Collins v. Eli Lilly Co., 342 N.W.2d 37, 49 (Wis. 1984); Martin v. Abbot Labs., 689 P.2d 368, 382 (Wash. 1984).

27. See, e.g., Sutowski v. Eli Lilly \& Co., 696 N.E.2d 187, 193 (Ohio 1998); id. at 190 n.1 (citing other jurisdictions rejecting market share liability).

28. Abraham, supra note 25 , at $965 \&$ n. 11 . 
Undaunted, Judge Weinstein has embraced the market share liability theory his decisions helped to inspire, and indeed, he has sought to extend it well beyond the special facts of Sindell. Most notably, in the Hamilton litigation, ${ }^{29}$ brought by shooting victims against gun manufacturers on claims of lax marketing practices, he deemed potentially viable under New York law a notion of "collective liability" according to which claims could proceed against each of forty-nine defendants, with liability apportioned among them. ${ }^{30} \mathrm{He}$ did so notwithstanding that market share liability is a fringe doctrine to begin with, and notwithstanding that three of Sindell's predicates-the likelihood that liability would be imposed only on actual tortfeasors, perfect product fungibility, and identical causal pathways linking each defendant's misconduct and each plaintiff's injuries-were missing. According to Judge Weinstein, it would be enough to impose joint liability if the plaintiffs could show that the manufacturers jointly "foster[ed] the growth of the underground gun market," and thereby made it possible for the persons who shot the plaintiffs to obtain the guns used in the shootings. ${ }^{31}$

Hamilton demonstrates similar expansionary inclinations on the question of what can count as a tortious "doing unto." Judge Weinstein was comfortable with the idea that carelessly making guns too readily available to those who later put them to unlawful use amounts to negligence as to the victims of those unlawful shootings. The New York Court of Appeals, by contrast, rejected this interpretation of state law, observing that it-like every other state high court-is "cautious" about, and indeed "resistan[t] to," the idea that an actor's failure to control the conduct of third persons so as to prevent them from wrongfully harming a victim can count as actionable negligence. ${ }^{32}$

Some of the same tendencies are on display in Judge Weinstein's treatment of fraud claims by purchasers of light cigarettes against cigarette manufacturers. His Simon II opinion certified a punitive-damages-only mandatory class action brought by consumers who alleged various illnesses resulting from the purchase and use of light cigarettes in reliance on the defendants' misrepresentations as to the cigarettes' lesser toxicity. ${ }^{33}$ The opinion duly notes the need for a fraud plaintiff

29. See Hamilton v. Accu-Tek, 935 F. Supp. 1307 (E.D.N.Y. 1996) (partially denying the defendants' motion for summary judgment); Hamilton v. Accu-Tek, 62 F. Supp. 2d 802 (E.D.N.Y. 1999) (denying defense motions for judgment notwithstanding the verdict and for a new trial), vacated, 264 F.3d 21 (2d Cir. 2001).

30. Hamilton, 935 F. Supp. at 1332.

31. Id. at 1330 .

32. Hamilton v. Beretta U.S.A. Corp., 750 N.E.2d 1055, 1055-57 (N.Y. 2001).

33. In re Simon II Litig., 211 F.R.D. 86 (E.D.N.Y. 2002), vacated, 407 F.3d 125 (2d Cir. 2005). 
to prove not merely that the defendant's intentional misrepresentations caused her harm, but also that the harm was caused by the plaintiff's reasonable reliance on those misrepresentations. ${ }^{34}$ Nonetheless, the Judge quickly elided this bit of blackletter law with a decision to certify for classwide determination the "estimated total value of national undifferentiated compensatory harm to all members of the class" 35 - a decision that emphasized the propriety of using statistical analysis to prove the aggregate amount of harm caused by the defendants' misrepresentations. Whatever these statistics might show, it is doubtful that they would reveal the extent to which the harm resulted from each plaintiff's reasonable reliance on the defendant's misrepresentations, which is in part why the Second Circuit reversed the certification ruling. The point is not that the putative victims in Simon II deserve more blame than Judge Weinstein was willing to give them. It is instead to note the lengths to which he has been willing to go to force certain allegations of wrongdoing into the tort mold.

Simon II also attests to another aspect of Judge Weinstein's willingness to reshape the idea of what counts as a tort claim. His decision to certify a punitive-damages-only class action was driven most immediately by strictures imposed by the United States Supreme Court on the use of class actions to resolve personal injury claims for compensatory damages. ${ }^{36}$ However, it was also predicated on a problematic conception of punitive damages. Judge Weinstein cast them, in essence, as a form of criminal punishment, administered on behalf of the public, to vindicate the public interest in penalizing conduct that is profoundly antisocial. As the Second Circuit noted, the Supreme Court has made clear that "conduct relevant to ... reprehensibility analysis must have a nexus to the specific harm suffered by the [tort] plaintiff, and ... [cannot] be independent of or dissimilar to the conduct that harms the plaintiff." 37 In other words, any punitive damages awarded to a tort plaintiff must reflect what the defendant has "done unto" the plaintiff, as opposed to the defendant's overall record of antisocial conduct. Here again, we see Judge Weinstein attempting to rework individualistic tort doctrine on collectivist terms. ${ }^{38}$

\footnotetext{
34. Id. at 140 .

35. Id. at 100.

36. Ortiz v. Fiberboard Corp., 527 U.S. 815, 864 (1999); Amchem Prods., Inc. v. Windsor, 521 U.S. 591, 628-29 (1997).

37. In re Simon II, 407 F.3d at 139.

38. I believe Judge Weinstein is also receptive to a capacious understanding of what can count as an injury that will support a tort claim. This much is suggested in some of his extrajudicial writings, which offer favorable assessments of the recognition by other courts of claims for in-
} 
Let me turn now, briefly, from individual to political responsibility. I noted above that tort law operates on a roughly Lockean picture of how the state interacts with citizens: loosely speaking, it serves as an umpire that declares standards of conduct, adjudicates disputes over those standards, and enforces them at the behest of claimants. Judge Weinstein's mass tort decisions depict citizen and state interacting on different terms.

As Martha Minow and others have emphasized, the Judge adopts in these and other cases a "public law" approach. ${ }^{39}$ This entails taking a view of the matter before the court that looks well beyond injurer and victim. The key, in his view, is to identify and respond to underlying patterns of injury and injury-producing behavior, much as a public health official might respond to the spread of an infectious disease, or a legislature might respond to a systemic problem such as widespread racial discrimination.

On this approach, a tort suit by a shooting victim against gun manufacturers is an invitation for the court to diagnose and respond to "gun violence," understood as a societal affliction. Expert evidence should be gathered to better grasp the scope of the problem. Perhaps input should be invited from affected populations and communities. A compensation scheme should be set up for victims, as should counseling and other support services. If possible, structural changes in the marketing of guns should be mandated through injunctive relief.

I noted above that tort law is meant to operate in a way that empowers victims: access to the courts, in principle, permits victims to assert themselves against those who have done them wrong. Reflective of his very different conception of government-citizen interaction, Judge Weinstein's approach to mass tort law in some respects downplays or even abandons this feature of tort law. On his view, judges hearing mass tort cases are charged with serving their community by seeing to it that justice, writ large, is done. Plaintiffs tend to be portrayed as victims of forces largely beyond their control. Indeed, Judge Weinstein's mass tort opinions and writings sometimes give off the impression that the only persons who exercise genuine agency, and who appropriately bear genuine responsibility, are corporate actors and government officials. Of course, there is an admirable, even astonishing, solicitude for plaintiffs to be found in Judge Weinstein's writings and in his work on the bench. As I noted at the outset, one

creased risk of disease, medical monitoring, and diminished "quality of life," among others. Weinstein, supra note 1, at 152-54.

39. Martha Minow, Judge for the Situation: Judge Jack Weinstein, Creator of Temporary Administrative Agencies, 97 Colum. L. Rev. 2010, 2026 (1997). 
would be hard-pressed to think of any judge who has done more for injury victims out of sincere empathy for their plight. But that, in a way, is my point. Here, victims are portrayed as persons who are entitled to a sympathetic ear and governmental assistance, not as persons whom the law stands ready to empower.

\section{Responsible JUdGing}

I have suggested that, in several ways, Judge Weinstein's mass tort jurisprudence has pushed tort law's concepts, categories, and presuppositions about as far as they can go and perhaps, on some occasions, too far. If this claim is correct, it raises the familiar question of whether, as a judge, he has acted in a manner that is inconsistent with conventional accounts of a trial judge's role responsibilities. Many have suggested that Judge Weinstein's approach to his job epitomizes "activism" - a term of opprobrium that suggests a failure to abide by the limits of the judicial office. ${ }^{40}$ Focusing again on his work in tort cases, I will argue that this charge is unfair for two reasons. First, his approach gibes with a mainstream and plausible, though certainly contestable, understanding of adjudication. Second, as he practices this approach, it often calls for greater fealty to tort law than alternatives that are sometimes falsely credited with demonstrating greater "restraint."

It is easy to offer superficial criticisms of Judge Weinstein's approach to mass tort claims. He is an outlier in his handling of them, and outliers cannot claim the easy legitimacy that comes with conformism. But of course it is hardly a sufficient basis for critique to observe that one judge in some respects goes about the job of deciding cases differently than other judges. To establish the serious charge of irresponsibility, one must offer an adequately defended account of what constitutes, or fails to constitute, responsible judging. Conversely, if it can be established that the outlier judge's way of deciding cases is consonant with a defensible conception of adjudication, the charge of activism, insofar as it is offered as a condemnation, carries no weight.

As it turns out, one can invoke two formidable authorities on behalf of Judge Weinstein's judicial efforts to push toward a more equitable "collectivist" conception of tort law: Oliver Wendell Holmes, Jr. and Ronald Dworkin. Each offered an account of adjudication according to which a judge adjudicates properly when he interprets and applies

40. See, e.g., Stephen B. Burbank, The Courtroom as Classroom: Independence, Imagination and Ideology in the Work of Jack Weinstein, 97 Colum. L. Rev. 1971, 1985-92 (1997). 
the law mindful of its normative "spirit" or direction. This, I would suggest, is exactly what Judge Weinstein has done.

Judge Weinstein's biographer, Jeffrey Morris, reports that while the Judge was a submariner in the United States Navy, he asked his mother to send him books on law. She sent a copy of Holmes's The Common Law. ${ }^{41}$ According to Morris, "[T]he young sailor . . . did not, apparently, understand much of [the book], but ... was fascinated by it." 42 Yet, whether by osmosis or subsequent exposure, Judge Weinstein seems to have grasped some of Holmes's most basic and arresting claims about law.

Holmes's classic book sought to show that it is characteristic of the common law to maintain the appearance of continuity even as it is undergoing a complete transformation. The "form and machinery" of the law, Holmes observed, is rooted in past practices and conventions. ${ }^{43}$ However, the "substance" of the law inevitably reflects the dominant spirit of the age. ${ }^{44}$ For example, the judges of Holmes's time still invoked the language of "fault" in resolving negligence claims. But that word, Holmes insisted, had lost its moralistic connotations and instead simply referred to an unreasonable failure to prevent a foreseeable loss. ${ }^{45}$ Just as criminal law had shifted from being a law of punishment to a law of deterrence, tort had shifted from being a law of private vengeance to a law that distributes losses on terms appropriate to a civilization that places significant value on freedom of action, and thus lets losses lie where they fall absent evidence that they were caused by the substandard conduct of another. ${ }^{46}$

On this understanding of Holmes, there is a distinctly Holmesian flavor to Judge Weinstein's approach to tort law. Lawyers, judges, legislators, and professors still invoke its traditional conceptual apparatus when analyzing the problems of mass personal injury litigation. But, Judge Weinstein would insist, this is just a matter of "form and machinery." Attention to the on-the-ground aspects of these cases reveals that they are today handled on very different terms than the individualistic model of tort law would suggest. Claims and parties are joined. Multidistrict Litigation proceedings are authorized. Ex-

\footnotetext{
41. Oliver Wendell Holmes, Jr., The Common Law (1881).

42. Jeffrey B. Morris, Leadership on the Federal Bench: The Craft and Activism OF JACK Weinstein 39 (2011). I recall a conversation with Judge Weinstein in which he offered a blunter recounting of this story-something to the effect of his not being able to make heads or tails of Holmes.

43. Holmes, supra note 41, at 2.

44. See id. at 2-3.

45. Id. at $107-10$.

46. $I d$. at $40-47,144$.
} 
pert evidence is developed on class-wide issues such as fault or general causation. Bellwether trials are held. Settlement grids are negotiated. As outlined above, various expansionary developments in substantive tort doctrine mirror these changes, again suggesting to Judge Weinstein that modern tort law is a qualitatively different creature from its prior iterations. Today, he maintains, tort law, or at least tort law applied on a large scale, is something very different than it once was. Roughly, it is a body of law that-not unlike certain aspects of the federal Superfund regime-authorizes judges to gather together all putative victims and all potentially responsible parties, and to oversee an equitable allocation of losses among them.

In short, just as Holmes believed that tort law had quietly shifted from being a law of private vengeance to a law for fairly allocating losses in a free society, Judge Weinstein believes that tort law has quietly shifted from implementing notions of individual responsibility to the realization of what some have called "localized distributive justice," 47 or what he calls "equity." According to both men, an understanding of the general tenor or spirit of the tort law of one's times provides grounds for, but also sets limits on, judicial efforts at doctrinal reform.

Holmes thought that a judge of his time should appreciate that tort law was coalescing around a single principle, namely, that one who acts so as to cause readily foreseeable temporal harm to another ought to bear the loss associated with the harm. ${ }^{48}$ A judge who appreciated this tendency within tort law would, in turn, be prepared to impose liability even absent blameworthy conduct by the defendant, and would recognize that he bears an onus of explanation for any decision denying liability in a case in which the principle is satisfied. ${ }^{49}$ Yet the same judge should also reject liability that is fully strict (in the sense of being imposed for unforeseeable losses). ${ }^{50}$ Judge Weinstein, as we have seen, supposes that a judge facing a mass tort case today should recognize the aptness of extended notions of joint liability such as enterprise and market share liability, as well as the need for relaxed standards for proof of causation, while at the same time appreciating that the goal of achieving localized distributive justice may call for

47. Stephen R. Perry, The Moral Foundations of Tort Law, 77 Iowa L. Rev. 449, 513 (1992). 48. Oliver W. Holmes, The Path of the Law, 10 Harv. L. Rev. 457, 471 (1897).

49. Id. (noting that terms such as "malice" and "negligence" as used in tort law should not be understood as importing moral notions of blameworthiness, and that decisions departing from the principle of liability for causing readily foreseeable temporal harm must be based on special grounds of policy).

50. Holmes, supra note 41, at 89-90 (arguing that precedent and policy both counsel against "absolute responsibility" in tort). 
compensation on a more modest scale than the traditional tort notion of make-whole compensation. ${ }^{51}$

I concede that the pairing of Judge Weinstein and Justice Holmes raises some obvious problems. The adult Holmes was an aloof, hardboiled Social Darwinist who showed little outward sympathy for the unfortunate.52 Judge Weinstein, to the extent he can be labeled, is a Kennedy-Johnson liberal. Holmes the skeptic became an unlikely hero to New Deal progressives by preaching restraint with respect to judicial review. ${ }^{53}$ No one has accused Judge Weinstein of being restrained. More generally, notwithstanding the deconstructive or skeptical aspects of his scholarly writing, Holmes, in his capacity as a judge, seemed mainly content to apply law in a relatively formalistic manner. ${ }^{54}$ This facet of his work was perhaps predictable. As Holmes described them in The Common Law, judges were in a significant sense passive. They could stake out distinct positions on particular issues, of course. But as members of the elite of a given era, they would inevitably tend to give expression to its dominant mores. Holmes simply thought judges would do better if they went about their jobs more self-consciously and with an appreciation of their limited ability to shape the course of events.

The mismatch between Judge Weinstein and Justice Holmes on adjudication leads us to Dworkin. For, whereas Holmes's work helps explain how Judge Weinstein's jurisprudence can be understood as resting on a historicist claim about the changing substance of the law, Dworkin's work helps explain why Judge Weinstein might be entitled to think that it is the job of a judge - a federal trial judge, no less-to guide and shape rather than simply ride the wave of history. For it was Dworkin who famously argued that it is the judge's duty to interpret law in a light that makes it the best it can be, relative to what

51. John C. P. Goldberg, Misconduct, Misfortune, and Just Compensation: Weinstein on Torts, 97 Colum. L. Rev. 2034, 2050-59 (1997) (arguing that Judge Weinstein's opinions and extrajudicial writings reject "make-whole" as the principle of compensation applicable to mass tort litigation).

52. Richard A. Posner, Introduction, in The Essential Holmes: Selections from the Letters, Speeches, Judicial Opinions, and Other Writings of Oliver Wendell Holmes, JR., at ix, xvi (Richard A. Posner ed., 1992) (describing Holmes as an "[a]theist, Darwinian, eugenicist, moral relativist, [and] aesthete").

53. See Brad Snyder, The House That Built Holmes, 30 Law \& Hist. Rev. 661, 664-67 (2012) (sketching ways in which Holmes participated in his "canonization" by progressives such as Felix Frankfurter and Walter Lippmann).

54. Thomas C. Grey, Essay, Molecular Motions: The Holmesian Judge in Theory and Practice, 37 WM. \& Mary L. Rev. 19, 27-28 (1995) (noting that Holmes's judicial opinions, with a few exceptions, were mainstream in terms of their reliance on precedent and statutory text). 
justice requires. 55 That, he insisted, is simply the proper way in which to engage in legal reasoning, at least in hard cases.

There is rather clearly a Dworkinian element to Judge Weinstein's famous effort in the Ashley decision to recast (and minimize) due process limits on personal jurisdiction. ${ }^{56}$ There is equally a Dworkinian element to Judge Weinstein's expansive understanding of what the substantive law of tort permits by way of liability. Both are controversial. But both attempt to reconstruct standard legal materials in a way that is responsive to them while shaping them in light of an aspiration to do justice that is taken to be implicit within them. By arguing that, within Rule 23, within common law precedents such as Summers and Sindell, within doctrines such as respondeat superior and strict products liability, one can find the seeds of a coherent account of modern mass tort law that best aligns it with the cause of justice, Judge Weinstein has arguably proceeded in good Dworkinian fashion. And insofar as he has, he can plausibly claim to have been going about the interpretive aspects of his job in a cogent and defensible manner.

In the end, one would need to examine more closely than I can here the particular interpretive "moves" Judge Weinstein makes to determine if his account of the contours of mass tort liability is a satisfactory exercise of Herculean legal reasoning. It may be that some are more plausible than others. And even if they paint a mostly compelling picture, this is by no means the only metric against which one can assess a judge's fealty to her office. For example, Dworkin's account of legal reasoning obviously does not speak directly to case management techniques. Thus, even if state and federal law is best interpreted to permit liability to be imposed on the terms on which Judge Weinstein would allow it to be imposed, some of his efforts to manage and bring to closure mass litigations might still be indefensible. Still, he would be able to plausibly claim to have been going about the interpretive aspects of his job in an entirely cogent and defensible manner. And that is no small matter given that there have been suggestions to the contrary. ${ }^{57}$

55. Ronald Dworkin, Law's Empire 225-29 (1986) (invoking the metaphor of the chain novel in support of the notion that judicial interpretation involves making extant legal materials the best that they can be).

56. Ashley v. Abbott Labs. (In re DES Cases), 789 F. Supp. 552, 579-80 (E.D.N.Y. 1992) (arguing that the minimum contacts test for due process limits on personal jurisdiction is best understood as instantiating a more general nexus text that might allow for jurisdiction to be asserted without territorial connections between the jurisdiction and the litigant).

57. In further defense of Judge Weinstein, it is worth pointing out that he is obviously aware that he is pushing the envelope and is also aware that appellate courts have shown themselves willing to rein him in when they think he has gone too far. Thus, he is essentially inviting the 
Let me conclude by mentioning two ways in which Judge Weinstein has been especially responsible in his handling of mass torts.

First, his "equitable" approach is rooted in a profound appreciation of the political ideals that undergird our system. ${ }^{58}$ In the Lockean language I used above, the state owes its citizens a right to law for the redress of wrongs. To say the same thing, there is a right to redress. In this respect, his work stands in sharp contrast to some surprisingly tone-deaf statements made by accomplished jurists who are wont to emphasize the importance of judicial adherence to original meanings and longstanding traditions.

Consider, for example, the eight-justice majority opinion in Riegel v. Medtronic, Inc., ${ }^{59}$ penned by Justice Scalia. Riegel deemed preempted a tort claim by a plaintiff against the manufacturer of an allegedly defective balloon catheter. In support of its reading of the preemption clause contained in the federal Medical Devices Amendments of 1976 (MDA), which extended the statute's preemptive effect beyond state regulatory law to tort law, the opinion reasons as follows:

State tort law that requires a manufacturer's catheters to be safer, but hence less effective, than the model the FDA has approved disrupts the federal [regulatory] scheme no less than state regulatory law to the same effect. Indeed, one would think that tort law, applied by juries under a negligence or strict-liability standard, is less deserving of preservation. A state statute, or a regulation adopted by a state agency, could at least be expected to apply cost-benefit analysis similar to that applied by the experts at the FDA: How many more lives will be saved by a device which, along with its greater effectiveness, brings a greater risk of harm? A jury, on the other hand, sees only the cost of a more dangerous design, and is not concerned with its benefits; the patients who reaped those benefits are not represented in court. . . .

... .

... It is not our job to speculate upon congressional motives. If we were to do so, however, the only indication available-the text of the statute-suggests that the solicitude for those injured by FDA-approved devices . . . was overcome in Congress's estimation by solicitude for those who would suffer without new medical devices if juries were allowed to apply the tort law of 50 States to all innovations. 60

appellate courts, both federal and state, to consider whether his reinterpretation of tort law is, by their lights, plausible. In many instances, they have concluded that it is not.

58. John C. P. Goldberg, Tort Law at the Founding, 39 FLA. ST. U. L. Rev. 85, 104-05 (2011) (discussing aspects of early American law evidencing a commitment to the notion of a right to law for the redress of wrongs); see also Goldberg, supra note 3, at 559-68 (same).

59. 552 U.S. 312 (2008).

60. Id. at 324-26 (citations omitted). 
There are a number of troubling statements in this passage. For one thing, it posits an inevitable trade-off between safety and efficacy, yet there is no reason to suppose that a finding of tort liability in this or other medical device cases would require devices to be "safer, but hence less effective." Under the products liability law of every jurisdiction, juries are entitled to conclude that a product is defective simply because it could have been made safer without a significant loss of efficacy. Even if one supposes that the FDA consistently makes sound decisions in approving medical devices, the MDA by its terms predicates approval only on a conclusion by the agency that there is a "reasonable assurance" of the device's "safety and effectiveness." 61 Agency approval, in short, is not tantamount to a finding that the device in question cannot be made safer without a loss of efficacy.

Moreover, the fact that tort law is applied by juries as opposed to experts hardly makes it "less deserving of protection," as Riegel contends. Indeed, one might have thought that, to someone like Justice Scalia, the tradition of civil jury trials, which traces back in this nation to its founding, and is enshrined for federal courts in the Seventh Amendment, makes it more deserving of protection. That is, unless one supposes, implausibly, that tort law must be understood as a poorly designed scheme of technocratic regulation rather than a law that allows victims to redress wrongs.

Also contrary to the Riegel opinion, there is every reason to suppose (absent inept lawyering by defense counsel) that the jury (and trial judge) will "see"-or at least hear about-the benefits of different design choices. Indeed, the benefits (and costs) of design choices are almost always at the very center of design defect litigation. ${ }^{62}$ Moreover, a jury will only consider the cost-benefit tradeoffs associated with different designs after the trial judge has rejected a defense motion for summary judgment arguing that, in light of the benefits of the defendant's design, no reasonable jury could deem that design defective. It is true, of course, that potential beneficiaries of more dangerous but more efficacious designs will not be parties to a tort suit asserting that the design was defective. But this, again, merely tells us that a tort suit is not an administrative proceeding. It is not a defect of the tort system that, in determining whether a driver has committed negligence, jurors do not see before them the potential beneficiaries of her aggressive driving.

61. Id. at 318 (emphasis added).

62. Restatement (Third) of Torts: Prods. Liability § 2(b) (1998) (offering a version of the risk-utility test that most jurisdictions use to determine whether a product design is defective). 
Finally, in positing that Congress acted out of solicitude "for those who would suffer without new medical devices if juries were allowed to apply the tort law of 50 States to all innovations," 63 Riegel reiterates some of the unfounded assumptions just noted, and also (as Justice Ginsburg stressed in her Riegel dissent) attributes to Congress a concern running directly counter to its long-standing acceptance of tort suits for drugs approved by the FDA. ${ }^{64}$ It also abandons what had been in the Court's jurisprudence a well-established presumption against preemption grounded in both federalism and individual rights concerns.

In sum, Riegel reasons in a way that badly mischaracterizes what tort law is, and the role that juries are expected to play in articulating that law. Most fundamentally, it wrongly converts what has long been understood as state law questions-such as the relevance of a manufacturer's compliance with safety regulations to the legal issue of whether its product was properly designed ${ }^{65}$-into something close to a federal common-law question of whether there is enough friction between state tort law and federal regulatory law that federal courts are entitled to decide of their own accord to shut down the operation of state tort law in a given domain. The Court's having done so is a serious departure from federalism, and a serious infringement on the right to redress. Riegel and other decisions, in which nominally "restrained" judges bend over backwards to find ways to limit the reach of tort law, render dubious any suggestion that Judge Weinstein has acted in a manner inconsistent with conventional notions of the judicial role.

Consideration of the second way in which Judge Weinstein has been especially responsible returns us to where we started, that is, by emphasizing the obvious. While certainly aggressive, his handling of mass tort cases has always gone hand-in-hand with the acceptance of a hyperdemanding conception of the responsibilities that attend his way of doing business. In designating and supervising special masters and expert witnesses; in issuing opinions exhaustively analyzing the factual and legal issues raised by complex cases; in holding attorneys' feet to the fire to resolve claims efficiently; in arranging for fairness hearings in his courtroom and around the country; in meeting with victims; in taking the time and effort to "write the book" on civil procedure, evidence, and mass torts; and in myriad other ways; Judge Weinstein has

63. Riegel, 552 U.S. at 326.

64. Id. at 340-43 (Ginsburg, J., dissenting).

65. Restatement (Third) of Torts: Prods. Liability § 4(b) (1998). 
accepted and lived up to his responsibility-to a superhuman degree-for what happens in and through his courtroom.

In this respect, Judge Weinstein's work stands in contrast to that of trial judges who, while equally keen to preside over mass litigations, seem at the same time content to delegate most of the difficult tasks associated with deciding these cases to lawyers and experts. The settlements that result from these sorts of proceedings risk harms to litigants, the law, and the legal profession. Here I have in mind the unseemly skewing of attorney-client relationships in the Vioxx settlement, ${ }^{66}$ as well as the prospect of indiscriminate recoveries against British Petroleum (BP) by claimants who, even under a broad reading of the federal Oil Pollution Act, lack colorable claims for economic loss. ${ }^{67}$

It is one thing for a trial judge to push on the law, and on the parties, to reach a settlement whose terms are crafted in the shadow of the law. It is another for a trial judge to cede to the plaintiffs' steering committee and defense counsel the authority to strike whatever deal they can, regardless of whether that deal bears any resemblance to what the law permits. Even if the lawyers and some of their clients are happy with the outcome, the court has an independent obligation to see that the deal reflects, or at least does not depart dramatically, from the law. To ignore this obligation is to fail in heeding an impor-

66. Howard M. Erichson \& Benjamin C. Zipursky, Consent Versus Closure, 96 Cornell L. REv. 265, 281-91 (2011) (identifying terms of the Vioxx settlement that violated applicable principles of legal ethics).

67. The author received compensation from the Gulf Coast Claims Facility, funded by BP, to prepare a report analyzing the scope of liability for economic loss resulting from the Deepwater Horizon oil spill. See John C. P. Goldberg, Liability for Economic Loss in Connection with the Deepwater Horizon Spill (Nov. 22, 2010), reprinted in 30 Miss. C. L. Rev. 335 (2011).

It may be that the terms on which BP settled the class action brought against it generated an obligation for the company to pay even for economic loss it did not cause. Certainly, there is nothing per se objectionable about such a settlement. More troublesome is the fact that the settlement was reached in part because the presiding district court judge declined even to sketch the legal limits of BP's liability under applicable federal law. In re Oil Spill by the Oil Rig "Deepwater Horizon" in the Gulf of Mexico, on Apr. 20, 2010, 808 F. Supp. 2d 943, 965-66 (E.D. La. 2011) (declining to outline limits on liability for economic loss under the federal Oil Pollution Act). Contrast Judge Weinstein's controversially aggressive signaling to lawyers for Agent Orange claimants that their clients' claims faced serious hurdles on issues such as proof of causation. Peter Shuck, Agent Orange on Trial: Mass Toxic Disasters in the Courts 159-61 (1986). I do not mean to take a position on the advisability of this particular tactic, nor to suggest that the same message should have been sent to plaintiffs' counsel in the Deepwater Horizon litigation. Rather, I mean to highlight Judge Weinstein's appreciation of the judicial obligations that come with his general approach to the resolution of mass claims, including the obligation to give the parties a relatively clear sense of the judge's understanding of applicable law. 
tant judicial responsibility. On this score, and many, many others, Judge Weinstein has been the very model of the responsible judge.

\section{CONCLUSION}

Judge Weinstein is many things. When it comes to mass tort litigation, he is the embodiment of all that is wise, honorable, and humane about the distinctively modern American enthusiasm for converting tort law - the law of private wrongs-into a public law scheme for allocating losses in the name of fair compensation. And unlike some armchair theorists, he appreciates and has worked relentlessly to resolve the endless and exhaustingly difficult real world problems entailed by that conversion project.

I happen to believe that it is a mistake to view tort law as a lossallocation mechanism. Such mechanisms ordinarily should be designed by policy makers, not judges, and should operate on rules quite different from those that we have had, and still have today. Tort law has long been, and continues to be, for and about something else-or so I have elsewhere argued. In the first instance, it allows victims to hold to account those who have wrongfully injured them. It is about responsibility, not compensation per se.

Perhaps it is too easy for me to take this position from the comfort of my own armchair, far removed from the front lines of trial court practice. And in this country at least, views such as mine are in the minority, whereas public law or regulatory views such as Judge Weinstein's tend to dominate. In any event, it is one thing to disagree with the Judge about the nature and arc of modern tort law. It is another thing entirely-and a thing entirely unwarranted-to see in his thoughtful and heroic efforts to articulate and realize his understanding of modern tort law some sort of intellectual or professional irresponsibility.

Perhaps one day I will see the error of my insistence that tort law is all about wrongs and redress, not compensation or deterrence. If so, it will be because Judge Weinstein will always be looking over my shoulder, rightly and forcefully insisting on attention to that which is genuinely important. In the meantime, I trust that it is appropriate even for an apostate to acknowledge his unpayable debts to, and his boundless admiration for, the master of the view from which he dissents. It is a rare thing to be touched by greatness. 